\title{
Cristianismo primitivo rumo à institucionalização: Contexto imperial romano (séc. I)
}

DOI: 10.15175/1984-2503-202113308

\author{
Ricardo Adriano Massara Brasileiro*
}

\begin{abstract}
Resumo
O presente estudo versa sobre a vivência da nova religião cristã no contexto imperial romano do primeiro século, buscando ressaltar alguns aspectos da sua primeira institucionalização. O cristianismo primitivo não era um movimento único. Ao contrário, refletia-se na existência de múltiplas pequenas comunidades domésticas, sem ortodoxia padronizada na fé, hierarquia eclesiástica ou instituições centralizadas. O estudo exporá as vias do espraiamento cristão através das infraestruturas imperial e sinagogal, bem como através do uso do referencial cultural grego. Tratará dos tipos dominantes de organização cristã, que se aproveitarão do arranjo socialmente arraigado da casa antiga patriarcal como arcabouço para o desenvolvimento institucional centralizado e hierarquizado que se firmará na cristandade, de forma análoga à arquitetura burocrática imperial.
\end{abstract}

Palavras-chave: cristianismo primitivo; século I; Igreja; império; institucionalização.

\section{Cristianismo primitivo rumbo a la institucionalización: contexto imperial romano (siglo I)}

\section{Resumen}

El presente estudio versa sobre la experiencia de la nueva religión cristiana en el contexto imperial romano del siglo I y busca resaltar algunos aspectos de su primera institucionalización. El cristianismo primitivo no era un movimiento único. Al contrario, estaba reflejado en la existencia de múltiples pequeñas comunidades domésticas sin una ortodoxia estandarizada en la fe, jerarquía eclesiástica o instituciones centralizadas. El estudio expondrá las vías de difusión cristiana a través de la infraestructura imperial y sinagogal, así como por medio del uso del referente cultural griego. Se tratarán los tipos dominantes de organización cristiana, que aprovecharán la disposición socialmente arraigada de la antigua casa patriarcal como marco para el desarrollo institucional centralizado y jerárquico que se asentará en la cristiandad, de manera análoga a la arquitectura burocrática imperial.

Palabras clave: cristianismo primitivo; siglo l; Iglesia; imperio; institucionalización.

\footnotetext{
* Procurador do Estado de Minas Gerais, professor adjunto da Faculdade de Direito Milton Campos, atuando na graduação e no mestrado, e advogado em Minas Gerais. Tem experiência na área de Direito, com ênfase em Direito Processual Civil, Direito Empresarial, História do Direito e Teoria do Direito.

E-mail: massarabrasileiro@gmail.com. http://lattes.cnpq.br/9708483814217990.

(1) https://orcid.org/0000-0002-9285-9327
} 


\title{
Primitive Christianity to institutionalization: Context of the Roman Empire (first century)
}

\begin{abstract}
The present study considers the experience of the new Christian religion in the context of the Roman Empire of the first century, seeking to highlight several aspects of its earliest institutionalization. Primitive Christianity was not a singular movement but was instead reflected in the existence of many small domestic communities without an orthodoxy standardized in faith, an ecclesiastical hierarchy, or centralized institutions. The study will reveal the ways in which Christianity spread through the imperial and synagogal infrastructures, as well as through the use of Greek cultural references. It will also discuss the dominant types of Christian organization, which would benefit from the socially entrenched arrangement of the old patriarchal house as a framework for the centralized and hierarchized institutional development to take root in Christianity, in a manner analogous to imperial bureaucratic architecture.
\end{abstract}

Keywords: Primitive Christianity; first century; Church; empire; institutionalization.

\section{Le christianisme primitif sur le chemin de l'institutionnalisation : le contexte impérial romain (ler siècle)}

\section{Résumé}

La présente étude s'intéresse à la vie de la nouvelle religion chrétienne dans le contexte impérial romain du premier siècle et cherche à mettre en lumière certains aspects de son institutionnalisation première. Le christianisme primitif n'était pas un mouvement uniforme. II se reflétait au contraire dans l'existence de nombre de petites communautés domestiques, sans orthodoxie normalisée de la foi ni hiérarchie ecclésiastique ou encore institutions centralisées. Ce travail exposera les voies de l'expansion chrétienne à travers les infrastructures impériales et synagogales, mais également en fonction de l'usage du référentiel culturel grec. Nous traiterons des types dominants d'organisation chrétienne qui sauront tirer profit de l'arrangement socialement enraciné du foyer patriarcal antique comme armature du développement institutionnel centralisé et hiérarchisé, qui gagnera en consistance dans la chrétienté de la même manière que l'architecture bureaucratique impériale.

Mots-clés : Christianisme primitif ; | ${ }^{\text {er }}$ siècle ; Église ; empire ; institutionnalisation.

\section{公元前一世纪原始基督教的制度化进程}

\section{摘要}

本文研究第一世纪罗马帝国背景下新生基督教的第一次制度化的历史过程。早期的基督教不是一个单一的运动， 相反，它分散在多个小型家庭社区里，没有等级差别，其信条也没有标准化，不存在等级化的教士群体与正规 化的教会。本研究认为，基督教的早期传播利用了罗马帝国的基础设施，采用了犹太教会的传教模式并吸收了 希腊文化。本文对一些占主导地位的基督教组织类型做了详细分类，这些组织根植于古罗马社会的社区父权制 生活方式，构建了原始基督教的集中制度和等级制度发展的框架，因此，早期基督教的机构运作方式颇类似于 帝国官僚机构的运作方式。

关键词：原始基督教；第一世纪；基督教堂；帝国；制度化。 


\section{Introdução}

O cristianismo surge como uma seita judaica, sucessora de um judaísmo já helenizado pelos mais de trezentos anos decorrentes das conquistas de Alexandre (336323). Sua originalidade somente se imporá aos poucos. Do helenismo retira algumas de suas crenças fundamentais, como a imortalidade da alma e a dualidade corpo material, mortal, versus alma imaterial, imortal (BAUMGARTNER, 2015, p. 35-39; ROBERTS, 2005, p. 147). Do contexto da história judaica, por outro lado, os cristãos extraíram, entre outras, as convicções apocalípticas de estarem vivendo os últimos dias, anteriores à chegada do Reino de Deus, deixando com isso, num primeiro momento, pouca margem para a ideia de uma Igreja com vivência histórica. Dos fins do primeiro século ate o século IV, quando ultimou-se a distinção definitiva entre cristãos e judeus em decorrência da atuação de autoridades eclesiásticas e rabínicas, cristianismo e judaísmo rabínico encontravam-se em processo continuado de formação cruzada, ambos reclamando a respectiva derivação da tradição de Israel (BRANDÃO, 2014, p. 151-152). O mundo antigo em que o cristianismo surge também é um espaço geopolítico imenso, considerado a oikumene, a orbis terrarum ou a terra habitada, com o centro político em Roma. A anunciação do Evangelho em toda essa latitude, esse ideal de universalismo, é a base de origem da catolicidade da doutrina da Igreja. ${ }^{1} \mathrm{O}$ bem estar social não era, no entanto, igualmente dispensado entre os vários povos, estando as diversas camadas da população fortemente dividida em classes. Roma jamais deixou de ser uma oligarquia; e mesmo a muitas vezes declamada república era para poucos (PARENTI, 2005). A vida cultural do império assentava-se nas artes e filosofia gregas e nas tradições jurídicas romanas, necessárias ao controle e à administração imperial. A vivência no contexto imperial é estritamente significativa para cristianismo primitivo, notadamente se se considera que a ideia de império projeta-se para além da Antiguidade após o colapso do Ocidente (STOCKMEIER; BAUER, 2013, p. 8 e 9, para o referenciamento geral).

Essa vivência da nova religião no contexto imperial do primeiro século é o assunto sobre o qual o presente texto se debruçará, buscando ressaltar alguns aspectos da sua

\footnotetext{
${ }^{1}$ A concepção de universalismo, contudo, já deriva da própria ideia de um Deus único, pois, se há somente um único e verdadeiro Deus, criador do céu e da terra, seu culto não deve encerrar-se a uma só nação. Encontrava-se, por exemplo, contida na mensagem de Isaias ("Sim, diz ele: Pouco é o seres meu servo, para restaurares as tribos de Jacó e tornares a trazer os remanescentes de Israel; também te dei como luz para os gentios, para seres a minha salvação até à extremidade da terra." - Isaías, 49, 6), a despeito de nunca ter sido levada a cabo pela ortodoxia judaica (GILSON, 2001, p. 181-193).
} 
primeira institucionalização. O estudo exporá as vias do espraiamento cristão através das infra-estruturas imperial e sinagogal, bem como através do uso do referencial cultural grego. Tratará dos tipos dominantes de organização cristã, que se aproveitarão do arranjo socialmente arraigado da casa antiga patriarcal como modelo de organização, a já fornecer um arcabouço para o desenvolvimento institucional centralizado e hierarquizado que se firmará na cristandade, de forma também análoga à arquitetura burocrática imperial.

A perspectiva de fundo para o desenvolvimento do texto, ao qual se pretende dar seguimento em outros estudos, é a da corporificação jurídico-institucional da Igreja Cristã, sob o modelamento imperial romano. A incorporação dessa matriz jurídica que impregnará a nova religião, no entanto, começa a ficar mais evidente a partir dos séculos II e III, quando escritores eclesiásticos apologéticos começam a referir-se ao direito romano para defender o cristianismo de múltiplas acusações; assim desenvolvem os primeiros esboços da doutrina cristã ocidental e constroem a ideia da Igreja como ordenamento, de modo a fortalecer sua estrutura em uma base universal e defender seu caráter de sociedade lícita (FANTAPPIĖ, 2011, p. 35-36). Desse modo, a juridicidade da institucionalização que se vai expor pode não parecer muito flagrante.

O estudo da matriz jurídica romana na cristandade ocidental pode encampar pelo menos duas visadas. Pode ser feito tanto pelo prisma da tradução da fé religiosa em termos de estruturação organizativa da Igreja, com características de autossuficiência análogas aos do ordenamento político - que é o que o texto começa a esboçar, guardada a advertência de que esse panorama fica mais claro nos dois séculos seguintes ao período analisado -, como, por outro lado, pode versar sobre o caráter jurídico dos agudos debates teológicos que marcaram os primeiros séculos da história cristã, em que a busca teológica de clareza da mensagem da salvação assenta-se sobre uma lógica racional e argumentativa que recorda vivamente o raciocínio jurídico (COLOGNESI, 2009, p. 439). Essa outra interessante questão, no entanto, não será objeto de abordagem direta deste estudo, em razão de já pressupor um maior adensamento institucional do corpus cristão.

O texto lidará com as fontes literárias primárias disponíveis, em especial, o próprio texto bíblico, submetido às críticas literária e histórica pertinentes. A tradução portuguesa do Novo Testamento que será referenciada é a recente versão transposta do grego por Frederico Lourenço (BÍBLIA, 2017, 2018), sempre cotejada com a versão mais tradicional no universo brasileiro, realizada por João Ferreira de Almeida (BÍBLIA, 2000), a cujo volume se recorrerá quando necessária a menção ao Antigo Testamento. Também serão aproveitadas 
fontes literárias e documentais romanas e cristãs primitivas na medida da exigência do texto, bem como alguma literatura de apoio, todas devidamente apontadas ao final.

\section{Primeiros tempos}

A ausência de fontes detalhadas torna difícil a recomposição histórica dos primeiros tempos. Muitas vezes segue-se o que se depreende dos textos bíblicos. Segundo uma narrativa tradicional, a Igreja supostamente nasceu já no primeiro Pentecostes, com a descida do Espírito Santo e a reanimação dos apóstolos (os enviados ou embaixadores, do grego apostoloi) à anunciação da palavra divina. O termo igreja provém do grego ekklesia, correspondente à assembleia dos cidadãos da polis, agora com a pretensão de significar uma comunidade fraterna. A pregação liderada por Pedro fez crescer enormemente o número de cristãos fiéis à Torá e às tradições judaicas. Mas foi, sobretudo, por obra de milhares de pregadores anônimos e missionários desconhecidos que o evangelho foi levado às mais diversas comunidades judaicas da diáspora. Dentre os muitos missionários, tem maior relevo a figura de Paulo (em verdade Saul ou Saulo, o nome do primeiro rei de Israel) - por sua atuação junto aos gentios. Paulo fundou inúmeras comunidades cristãs capazes de existir autonomamente em territórios hoje correspondentes à Síria, à Turquia, à antiga lugoslávia, à Grécia e ao Chipre. Paulo eventualmente as visitava e com elas eventualmente se correspondia, sempre com a mensagem de que essas diversas comunidades pertenciam a uma única e só Igreja, gerando uma ideia de solidariedade e evitando a separação de cristãos de origem judaica e pagã, mas igualmente tornando a cristandade uma religião universal - ou seja, literalmente, católica -, igualmente aberta a pessoas livres e escravas, do sexo masculino e feminino, bem como a qualquer grupo étnico. Para Paulo não havia a necessidade de ser antes judeu para, somente depois, tornar-se cristão. Dispensava, por exemplo, a imperiosidade da circuncisão, que, em termos judaicos, seria o próprio distintivo da aliança com Deus na carne - mas que para os gentios não passava de uma mutilação despropositada - , tal como supostamente imposta pelo próprio D-us [segundo preceitos judaicos seu nome não pode ser escrito] a Moisés, bem como dispensava ou atenuava muitas das excessivas exigências da lei mosaica, notadamente, à mesa, como a reserva à carne suína, a renúncia à carne dos animais sacrificados em ritos pagãos e o impedimento de sentar-se à mesa com os não-judeus. (A propósito: BAUMGARTNER, 2015, p. 49-53; CANTOR, 2004, p. 37-38; CITRONI et al., 2006, p. 1.017-1.020; HOLMES; BICKERS, 2006, p. 24-27; STOCKMEIER; BAUER, 2013, p. 12-14). 
As primeiras comunidades cristãs, no entanto, formavam um grupo um tanto disperso de crentes, sem qualquer organização especial, sem ortodoxia padronizada na fé, hierarquia eclesiástica ou instituições centralizadas. Isso refletia a própria diversidade do cristianismo do século I, que não era um movimento único e unificado ou uma religião claramente diferenciada das variedades de judaísmo antigo. Jesus não havia deixado qualquer mensagem escrita, de modo que sua pregação era apropriada de modos muito discrepantes pelas distintas comunidades, já diferenciadas entre si pela interação com circunstâncias humanas, históricas e geográficas diversas. Esses primeiros cristãos, em realidade, estavam criando diferentes, mas relacionadas, formas de cristandade (POLLINI, 2017, p. 223). Os distintos grupos fracionados dividiam expressões de solidariedade, mas também buscavam uma autodefinição, com a construção de fronteiras entre si, por diferentes práticas rituais e escriturais e por distintos ensinamentos sobre Jesus. O uso do termo Igreja, com a primeira letra em maiúscula, a significar uma instituição ou um corpo social organizado, parece um tanto anacrônico para a época em exposição (HARRIL, 2017, p. 278-279, para o referenciamento geral; MCKENZIE, 2007, p. 200, nota 8).

\section{Cristianismo no centro do império e nas capitais culturais e administrativas das províncias}

Conforme relato de Suetônio, o imperador Cláudio (imperador de 41 a 54 d. C.) teria expulsado de Roma os judeus "que instigados por um tal Chrestus, provocavam frequentes tumultos" (Livro V, XXV) (SUETÔNIO, 2007, p. 286). Tal fato teria possivelmente ocorrido em torno do ano 49 (POLLINI, 2017, p. 223; 230). Dion Cassio (LX 6, 6), por seu turno, relata que o imperador Cláudio, em sequência à sua entronização - ou seja, em torno de nove anos antes - , deixou de expulsar os judeus de Roma, para não causar tumulto entre eles, em razão do seu elevado número, mas proibiu-lhes as reuniões, quando da manutenção de seus costumes tradicionais (CASSIUS DIO, 1924; DION CASSIUS, 1866). Se este primeiro evento também já se refere a uma repreensão à prática cristã, causadora de tumultos entre os judeus, tanto significa que em apenas cerca de dez anos após a morte de Jesus, o cristianismo já encontrara o centro do império (EBNER, 2012, p. 25). Por outro lado, a se fiar na propriedade do relato de Suetônio, o encontro com a capital do império teria ocorrido poucos anos depois. O relato de Suetônio, no entanto, data possivelmente de 119-122 (HARRIL, 2017, p. 285), enquanto o de Dion Cássio foi possivelmente redigido entre 202 e 214 (ROBERTS, 2005, p. 135), de modo que não são contemporâneos aos 
fatos narrados e deles distam em torno de 70 e 160 ou 170 anos. Há autores que consideram não ser inteiramente segura a assimilação do Chrestus apresentado por Suetônio com a figura de Cristo, mas que, de toda sorte, já assumem como existente a presença cristã em Roma nessa mesma época, em torno dos anos 50 , tal como se extrai da carta de Paulo aos romanos (SIMONETTI, 2010, p. 1441), que constitui a melhor evidência primária do tema (HARRIL, 2017, p. 277).

É curioso ressaltar que era comum aos autores latinos a flutuação entre Christus/Chrestus e chistianus/chrestianus, em decorrência da variação grega khristós/khrestós, ambas pronunciadas do primeiro modo, mas com significações e etimologias distintas, a primeira referenciando ao "ungido", ao "consagrado", e a última ao homem "honesto", "honrado", "virtuoso", "devotado", "nobre" - e de uma perspectiva política, os melhores dentre os cidadãos - , com o que se chegou a colocar a hipótese que os primeiros cristãos conscientemente assumiram a segunda forma ao se autodesignarem (BRANDÃO, 2014, p. 78-80, principalmente; CITRONI et al., 2006, p. 1.018; CONSTANCIO, 1836, p. 258; LACTANTIUS, 2003, p. 234, nota 25). ${ }^{2}$ Já no início do século IV, contudo, o retórico Lactâncio - conselheiro de Constantino (HARRIL, 2017, p. 288), o primeiro imperador cristão, e preceptor do seu filho Crispo (CITRONI et al., 2006, p. 1073) - talvez não fortuitamente atribua a troca de Christus por Chrestus ao uso de gente ignorante, que desconhece o significado nobiliário do termo, que expressaria as ideias de poder e realeza entre os judeus, que assim supostamente designavam seus reis (LACTANTIUS, 2003, p. 234, livro 4, 7.4-7.5). Nos primeiros tempos, contudo, o designativo cristão parece referir-se a algo desonroso, que poderia ser traduzido como "fãs exagerados" ou "turba política "do Ungido" (RUDEN, 2013, p. 12). Todas as formas de cristianismo, baseadas ou não na Torá, eram reputadas heresia ou blasfêmia pela ortodoxia judaica, a ser punida com a morte, por apedrejamento, segundo a Lei judaica (Deuteronômio 13, 1-10 e 17, 2-7). O gentio politeísta, por outro lado, tendia a considerar os cristãos como ímpios ou ateus, por negarem suas deidades, que eram consideradas falsas ou demoníacas pelos que cultuavam um único Deus. Tudo isso combinado com a passionalidade, a imoderação e o estranhamento ao mundo resultantes da crença apocalíptica da iminência do fim dos tempos, não raro resultava em perturbação da paz dos deuses (pax deorum), tão cara aos romanos (LE GLAY et al., 2006, p. 251-252; POLLINI, 2017, p. 225-226; STOCKMEIER; BAUER, 2013, p. 16). Isso

\footnotetext{
2 Constancio (1836), a despeito de sustentar a existência de concórdia acerca de o termo significar "ungido", afirma que ele próprio se inclina a tê-lo derivado de "áureo", "luminoso".
} 
talvez justifique a discreta ocorrência do termo no Novo Testamento, em que comparece unicamente 3 vezes, sempre em textos tardios e pseudonímicos (Atos 11, 26 e 26, 28 e 1Pedro 4, 16) (BÍBLIA, 2018, p. 43-46, 487-488; 499).

Em qualquer hipótese, em 25 anos da execução de Jesus, o rol de saudações da Carta aos Romanos $(16,3-16)$ testemunha a existência de sete comunidades domésticas na Urbe (EBNER, 2012, p. 25). As minúsculas comunidades cristãs eram fracionadas em várias congregações domésticas, que não se diferenciavam de modo muito evidente das variedades de judaísmo antigo, nem constituíam qualquer movimento único e unificado, tal como se tratou há pouco. As primeiras congregações romanas surgiram entremeio às vastas comunidades judaicas da capital, concentradas em localidades habitadas pelos estrangeiros (peregrini) mais pobres. Eram vizinhanças apinhadas, recortadas pelas principais vias por onde multidões de imigrantes e viajantes aportavam em Roma (HARRIL, 2017 , p. 279). Uma imagem mais própria talvez seja a de grandes cortiços ou favelas verticalizadas, com edificações precárias, sem condições sanitárias adequadas, alugadas por preços exorbitantes (PARENTI, 2005, p. 40).

A urgência escatológica determinou pressa na difusão da mensagem da salvação. A estratégia foi o ataque ao império mundial. Missionários não somente se instalaram na capital - onde se encontrava a maior colônia judaica da diáspora, estimada entre 30 e 50 mil membros (LE GLAY et al., 2006, p. 251) - , como também se valeram da ampla infraestrutura imperial, como estradas, calçadas, portos e rotas marítimas pacificadas, para instalarem-se nos diversos centros administrativos, nas capitais das províncias e nas cidades veteranas através das quais o império era regido e que desempenhavam o papel de ilhas culturais no então chamado mundo conhecido. Nos escritos de Paulo pode-se verificar a presença de sua missão nessas localidades e que o apóstolo pensava a partir das categorias administrativas romanas (1Coríntios 16, 15, 19; 1Tessalonicenses 1,7; Romanos 15, 18 s.). Uma vez nas cidades imperiais, buscava-se o aproveitamento da infraestrutura sinagogal-helenística, admitida pelos romanos como collegia licita, dada a possibilidade de, nela, qualquer judeu fazer o uso da palavra (EBNER, 2012, p. 25-26; 44; JOSSA, 2007, p. 12; STOCKMEIER; BAUER, 2013, p. 16). Paulo, que era judeu helenizado da diáspora, talvez raciocinasse a partir dessas reportadas categorias em razão de possivelmente possuir a cidadania romana, talvez adquirida por seu pai. Era fluente em hebraico e grego e versado em filosofia, religião, literatura, retórica e eloquência helênicas. Tradicionalmente diz-se que foi acusado de subversão, possivelmente por rabinos, preso e 
conduzido a Roma (Atos 28, 16) e lá martirizado durante o governo de Nero (em torno de 66 d.C.) (CANTOR, 2004, p. 37; MURPHY-O'CONNOR, 2008, p. 50-53; RUDEN, 2013, p. 9-11). Há argumentos bastante plausíveis, no entanto, de que sequer tenha estado na Urbe (HARRIL, 2017, p. 276-289; POLLINI, 2017, p. 233)

A maior parte dos primeiros esforços missionários voltou-se para porções helenizadas do povo judeu, que poderiam ser encontradas em todas as maiores cidades do mundo mediterrâneo e que se caracterizavam, no mais das vezes, por classes educadas, aristocráticas ou comerciais, em que o grego era a língua franca. E boa parte do sucesso dessas missões em sua expansão pela Palestina e além deveu-se ao aproveitamento de muitas racionalidades, categorias de pensamento, conceitos, metáforas e conotações de sentido próprios da língua grega, que foram apropriados pelo pensamento cristão. A primeira literatura cristã é expressa em grego, muitas vezes valendo-se de estilos e formas literárias gregas, como epístolas e atos ou praxeis, em conformidade, respectivamente, com modelos de exposição dos filósofos da Hélade ou com relatos de feitos e lições de sábios ou homens de fama, reportados por seus discípulos (JAEGER, 2002, p. 14-26). O grego foi a língua de composição do Novo Testamento e era a língua em que os antigos textos sagrados eram conhecidos pelos judeus helenizados, através da chamada versão "dos Setenta" ou Septuaginta, traduzida em Alexandria no séculos III a.C. Na própria Roma, onde surgiu a literatura cristã latina, precederam escritores de língua grega. O latim como língua literária cristã somente se terá como assentado em meados do século III, quando da substituição do grego como língua litúrgica no seio da comunidade cristã (BÍBLIA, 2017, p. 15-16; CITRONI et al., 2006, p. 1025-1027). Há autores que sustentam que o próprio alvo final do cristianismo era o mundo grego clássico, o que se poderia aferir pela pregação de Paulo em Atenas, antiga capital cultural da Grécia e símbolo da sua tradição histórica, tanto na sinagoga como na praça pública, para filósofos estoicos e epicuristas (JAEGER, 2002, p. 24-26), o que relatado no Atos dos Apóstolos 17, 16-34. Há quem insista, por outro lado, que Paulo tenha pensado a partir das reportadas categorias administrativas romanas, tendo como significativa a circunstância de o apóstolo ter preferido Corinto, capital da província romana da Acaia, a Atenas, como localidade para fundar uma congregação cristã (EBNER, 2012, p. 26), cidades hoje distanciadas uma da outra em aproximados 80 kilômetros.

Por longo tempo o cristianismo permaneceu como uma manifestação notadamente urbana, tendente a difundir-se por toda a extensão do império. Isso, no entanto, não significa 
que os cristãos tenham incorporado em hábitos a vida e as instituições da civilização grecoromana. Ao contrário, não participam da vida pública das cidades que vivem, levando uma vida de corpo separado, o que lhes atrai as suspeitas e desconfianças dos demais habitantes dos lugares (JOSSA, 2007, p. 14). Nesses primeiros tempos o tornar-se cristão significava uma forte mudança social. As associações domésticas consideravam-se uma nova família, resistentes à prática de outros cultos, sendo tendencialmente vedados ao novo membro inclusive os cultos domésticos da sua família de origem. Os cristãos tratavam-se por irmãos e irmãs, encorajando as pessoas a se isolarem do mundo circundante e a se transformarem em membros de um novo signo identitário, sob um novo nomen, o nomen christianum, não mais o nomen romanum ou qualquer outro. As hostilidades, portanto, eram de se esperar, sejam elas da comunidade política - que reputava a ausência nos cultos públicos como atitude anti-romana e anti-estatal - , seja das antigas formas de identificação e dos relacionamentos preexistentes do novo membro (HARRIL, 2017, p. 278-279; POLLINI, 2017, p. 227-228). A circunstância de os seus ritos serem privados e rodeados de segredo faziam com que fossem acusados de incesto, infanticídio, ou antropofagia, por comungarem do corpo e do sangue de Cristo. Uma reação pagã mais ou menos orgânica, no entanto, somente surgiu a partir do início do século II, a partir da pena de homens ilustres e representativos da época, como o filósofo estóico-cínico Epíteto - que critica os que ele chama de galileus por uma postura que não lhe parece moralmente convincente, nem moralmente fundada diante da morte, a despeito de supostamente inspirada na liberdade e na coragem - e alguns representantes da aristocracia romana, como Plínio, o Moço - que, quando do exercício do proconsulado na província romana da Bitínia e Ponto, na Ásia Menor, em torno do ano 112, legou correspondência ao imperador Trajano, que é a referência pagã sobrevivente mais antiga sobre os cristãos (PLÍNIO..., 2018, p. 82-84, Carta 96) - , seu assistente Suetônio (2007, p. 314; Nero, Livro VI, XVI) e seu correspondente Tácito (2010 Annales, 15, 44), que sublinham a incompatibilidade da nova religião com os princípios sacros da tradição romana. Os últimos autores sequer consideravam a nova religião propriamente como religião, mas como uma mera superstição tola e extravagante, donde resultou uma duradoura pecha infamante aos cristãos, que remanesceu até Constantino, resumida na expressão empregada por Suetônio: superstitio nova et malefica. A rejeição pública muitas vezes resultou em denúncias anônimas e não anônimas às autoridades romanas - as primeiras a serem rejeitadas de plano e as últimas que deveriam conduzir à condenação somente em caso de culpa formada - , por si sós suficientes para introjetar nos 
primeiros cristãos sentimentos de receio, precariedade e perigo, ainda que inexistisse propriamente um estado de persecução. Antes de 250, os episódios ocorridos foram esporádicos, sem qualquer intenção política clara de extinguir a nova religião (BONI, 2014; EUSÉBIO DE CESARÉIA, 2019, p. 123-124; IV, 9, 1-3; JOSSA, 2007, p. 18-19; LE GLAY et al., 2006, p. 250; LE ROUX, 2009, p. 116-119; PIERINI, 1998, p. 57; PLÍNIO..., 2018, p. 8284, Carta 96; Carta 97).

\section{Rumo à institucionalização}

Conforme mencionado, nas comunidades cristãs do primeiro século não havia ortodoxia padronizada na fé, hierarquia eclesiástica ou instituições centralizadas. Isso, no entanto, não significa que os primeiros cristãos se criaram no vazio institucional, sem necessidade de interação com arquiteturas sociais já sedimentadas ou alheios à consolidação de papéis sociais e estruturas grupais em decorrência do convívio demorado. A circunstância de se reunirem em casas particulares, por exemplo, fez com que que necessariamente interagissem com a casa antiga, um arranjo institucional arraigado como uma unidade econômica, patriarcalmente conduzida com rigidez pelo pater famílias, a quem convergiam as forças legais e econômicas. A ele competiam poderes de representação externa, administração, distribuição de tarefas e jurisdição internas. Assim, muitas situações organizacionais se desembaraçavam com a mediação dos senhores das casas em que se reuniam as diversas comunidades domésticas. Esse mesmo arranjo, por outro lado, já fornecia a base da futura forma organizacional que se consolidará na cristandade, conhecida como episcopado monárquico, com um monoepíscopo responsável pela ordem e pela doutrina em toda uma gama de comunidades domésticas de uma mesma base territorial, todas reputadas a sua casa (EBNER, 2012, p. 33).

Por outro lado, no início, os apóstolos eram os dotados da autoridade suprema na Igreja. As comunidades locais que tinham sido por eles fundadas gozavam de reputação supra-regional e legitimação dos estilos próprios de culto e condução da vida. Após as respectivas mortes, é que a questão da liderança e da autoridade se mostrava de maior complexidade (HOLMES; BICKERS, 2006, p. 31; STOCKMEIER; BAUER, 2013, p. 17).

Por inexistirem formas homogêneas de organização, a literatura especializada costumeiramente trabalha com os dois modelamentos institucionais dominantes, que, no entanto, não contrastavam entre si e terminaram por mesclar-se e se superpor: o das 
comunidades judaico-cristãs e o das comunidades criadas pelo apóstolo Paulo ou a ele ligadas (EBNER, 2012, p. 33-34; FANTAPPIĖ, 2011, p. 34; STOCKMEIER; BAUER, 2013, p. 12-14; 19).

Enquanto se mantiveram fiéis à Lei mosaica e ao Templo, as comunidades cristãs primitivas de Jerusalém não se distinguiam, do ponto de vista externo, das demais comunidades judaicas. Elementos de diferenciação do culto cristão primitivo, a exemplo do batismo como rito de iniciação e da partilha do pão - agora como ritual eucarístico (do grego eu-charistein, ação de graças) e refeição sagrada (a rememorar a última refeição de Cristo) e não unicamente o ato pelo qual o pai de família começava a refeição no judaísmo - , induziram à formação de comunidades domésticas, consideradas as primeiras igrejas, em que se liam textos sagrados e se praticavam salmos e orações, com o esboço de uma liturgia básica (Atos dos Apóstolos, 2, 38, 42 e 46). Usualmente seguia-se o modelamento organizacional da sinagoga judaica. O fator distintivo fundamental era a constância da memória de Cristo, que passou a ser percebida publicamente de modo progressivo. Nas fases iniciais, a colegialidade comparece como característica da constituição das comunidades. Nesta cidade, Tiago, Pedro e João exerceram a liderança desde cedo, secundados por um colégio de anciãos (presbíteros), a quem competiam, tal como na sinagoga, atividades organizacionais e caritativas. Em assuntos de maior relevo, toda a comunidade tomava parte, considerada a crença veterotestamentária de que, na assembleia, Deus falava diretamente (BAUMGARTNER, 2015, p. 53-54; JOSSA, 2007, p. 14-15; STOCKMEIER; BAUER, 2013, p. 9-10; 19). Esse modelo - marcado pelo traço aristocrático da submissão das diversas comunidades domésticas à coordenação do conselho de anciãos - derivou de uma adaptação das experimentações das comunas das cidades pelas agremiações sinagogais judaicas e findou por constituir-se no próprio esquema organizativo que primeiramente se estabeleceu nas comunidades judeo-cristãs ou cristãs de tendência judaizante, mais fortemente assentadas nos territórios de Jerusalém e da Palestina (EBNER, 2012, p. 34; FANTAPPIĖ, 2011, p. 34).

Por outro lado, numa ampliação do modelamento cultural grego, Paulo entendia as diversas comunidades domésticas de uma cidade como uma assembleia geral, em que tinham voz não unicamente os cidadãos plenos do sexo masculino, mas igualmente as mulheres e os escravos (Gálatas 3, 26-28; 1Coríntios 12, 13), que, como cidadãos plenos da ekklesia, podiam votar e participar das deliberações, que se construíam por maioria. Tal como os demais membros da comunidade, mulheres e escravos também desempenhavam diversos cargos ou funções, designados pelo apóstolo como carismas, termo grego que 
significa "dons espirituais particulares (BAUMGARTNER, 2015, p. 55; EBNER, 2012, p. 34). Paulo, como apóstolo, sustentava a preeminência de sua autoridade na revelação divina (1Coríntios 9, 1; 15, 8-10; Gálatas 1, 1, 12, 15-16). Na base da diferenciação funcional, por outro lado, inexistia qualquer esquema organizacional muito fixo, mas sim algo mais espontâneo, determinado ao sabor das necessidades e dos melhores dons (1Coríntios 12, 31; Romanos 12, 6). Mas a par dos carismas momentâneos, Paulo versa sobre os serviços mais duradouros (1) daqueles que se esforçam para governar e instruir as comunidades no Senhor, a quem deve ser dedicado um amor amplificado em razão da sua obra (1Tessalonicenses, 5, 12-13), bem como (2) dos seus respectivos servidores, ambos, "supervisores" e "servidores", designados pelo apóstolo por epískopoi e diákonoi (Filipenses 1,1), palavras que posteriormente passariam a significar "bispos" e "diáconos". Paulo concebia os distintos ministérios ou serviços como manifestações do espírito a serem utilizadas em benefício comum ("a cada um é dada a manifestação do espírito para o proveito comum" - 1Coríntios 12, 7). Sua variedade, no entanto, não contrastava com uma ordenação funcional interna, de modo a resultarem enumerados e hierarquizados pelo apóstolo numa carta com propósito de apaziguar conflitos e constituir maior ordem na comunidade de Corinto:

Vós sóis corpo de Cristo e membros de [um] membro. E aqueles que Deus estabeleceu na assembleias [são], em primeiro lugar, apóstolos; em segundo, profetas; em terceiro, mestres; depois, milagres, depois, dons de curas, auxílios, administrações, variedades de línguas. (1Coríntios 12, 27-28)

Dos serviços enumerados, enquanto os bispos e diáconos estavam usualmente vinculados a comunidades locais, os apóstolos, profetas e mestres - em outras palavras, missionário, pregador e docente - atuavam num âmbito mais expandido. Nas comunidades paulinas, em todo caso, mesmo as liberdades carismáticas deviam se desenvolver com decoro, ordem (1Coríntios 14, 40) e submissão (1Coríntios 16, 15-16; 1Tessalonicenses 5, 12) (BAUMGARTNER, 2015, p. 56; STOCKMEIER; BAUER, 2013, p. 19). A ideia de subordinação paulina, no entanto, considera que o serviço acometido a cada um é um serviço de todos - a condução recíproca para o bom caminho -, de modo a não possuir caráter institucional e absoluto, mas funcional e relacional; afinal os dons, os serviços e as ações de cada qual nada mais são do que próprio recurso básico e comum de todos, o mesmo espírito, o mesmo Senhor, o mesmo Deus (1Coríntios 12, 4-7) (EBNER, 2012, p. 42-43).

Aquele modelo aristocrático das comunidades judeo-cristianas, no entanto, em pouco tempo se superpôs às congregações paulinas. Em duas gerações posteriores ao apóstolo, 
as cartas pastorais - falsamente atribuídas a Paulo - já pressupunham um colégio de presbíteros. Ao fim do século I, as atividades de administração e ensino, bem como as atividades espirituais e litúrgicas já competem a esse colégio de anciãos, que, por vezes, passam a ser designados também como epíscopos. A conjunção desse colégio com a visão de Paulo da ekklesia como casa, conduziu à redução do colégio de presbíteros a um só, a um único epískopo, que assumirá as funções diretivas, paralelamente à figura do pater famílias. Agora, as mulheres são veementemente remetidas da vida pública comunitária para a casa, subordinadas à proteção de um senhor, com deveres de oração e parturição (1Timóteo 2, 9-15; 5, 14) - enquanto para o Paulo autêntico, ao contrário, num "mundo [que] ficou curto", o recomendável era a castidade: "no que respeita às virgens [...] Julgo que isso é bom, por causa da presente angústia: é bom a pessoa continuar assim." (1Coríntios 7, passim, especialmente 7, 8, 11, 25-26, 29, 36, 40) (BÍBLIA, 2018, p. 153-156) -. A subordinação igualmente se estende a crianças e escravos. A mudança deveu-se tanto ao propósito de enfrentamento aos falsos mestres (1Timóteo 1, 3; 4, 1-5; 2Timóteo 3, 6-9), que devem ser combatidos através da rigidez disciplinar e da centralização, como ao intuito de longo prazo de integração à sociedade romana (1Timóteo 2, 2; 3, 7), dominada por modelos patriarcais (BAUMGARTNER, 2015, p. 57; EBNER, 2012, p. 33; 35; 41, principalmente).

Do universo de 13 cartas imputadas ao apóstolo no texto bíblico, há concordância entre os especialistas que somente 7 delas são autênticas: Romanos, 1 e 2 Coríntios, Gálatas, Filipenses, 1 Tessalonicenses, e a carta a Filêmon (BÍBLIA, 2018, p. 149-156; GOULDER, 1997, p. 515; JOSSA, 2007, p. 16-17; MCKENZIE, 2007, p. 160; RUDEN, 2013, p. 13;). Posteriormente à morte do apóstolo, as posições de Paulo tenderam as ser interpretadas anacronicamente, de um modo universalizado. Para a correta interpretação das cartas, deve-se compreender que Paulo (1) viveu convicto da iminência do apocalipse ainda na sua própria geração (1Tessalocicenses 4, 13-8; 1 Coríntios 15, 51-52; Romanos 13, 11-12), sem qualquer expectativa de futuro, e que (2) escreveu todas as suas cartas endereçadas a uma audiência específica, para responder a problemas concretos, e não como um compêndio atemporal da fé cristã, a ser incorporado no Novo Testamento - livro até então inexistente, cujos primeiros escritos são precisamente as cartas autênticas de Paulo, sendo os demais escritos posteriores ao óbito do apóstolo - . A tendência da aplicação universal das cartas apostólicas evidenciou-se no século II, quando as comunidades cristãs se encontravam mais estabelecidas e confiantes na existência de um futuro continuado. Tertuliano de Cartago (apologeta dos séculos II e III, que viveu 
aproximadamente entre os anos 160-230), por exemplo, sustentou que quando Paulo escrevia para uma igreja, ele, na verdade, escrevia para todas (Contra Marcião, 5.17.1). A propensão ao entendimento generalizante das cartas do apóstolo, aliás, foi o que encorajou a produção de cartas gerais, usualmente tardias e pseudoepigráficas (BÍBLIA, 2018, p. 150151; 293; HARRIL, 2017, p. 283; MCKENZIE, 2007, p. 159-160; 200).

De toda sorte, a insistência paulina na unidade orgânica da ekklesia, que comporia um único corpo em Cristo, primeiramente exposta com o propósito de dissuasão de desavenças na comunidade de Corinto (mas depois aludida brevemente em Romanos 12, 4-8), tendeu a ser interpretada como uma prescrição universal a justificar um sentido de corresponsabilidade entre as diversas igrejas locais pelos rumos da cristandade, que findou por conduzir a uma própria estruturação hierarquizada da Igreja nos séculos subsequentes, o que já esboçado na Carta de Clemente aos Coríntios, nos finais do século I, e na correspondência de Inácio de Antióquia, dos primeiros 20 anos do século seguinte, num claro paralelismo da estruturação eclesiástica com o modelamento da administração estatal (BAUMGARTNER, 2015, p. 42; COLOGNESI, 2009, p. 439; LE GLAY et. al., 2006, p. 494-495).

O argumento de Paulo, em boa medida ecoado por Clemente (1Clemente, 37, 1-5), lida com uma imaginária disputa entre os membros do corpo humano. Nesse ponto, Paulo se valeu de uma fábula integrante das tradições romana e grega para a exortação de dissidentes à união em um só corpo, como única forma de sobreviver e existir. Tito Lívio (II, 32), por exemplo, fala da sua utilização por Menênio Agripa, um "varão eloquente e estimado pelo povo por suas origens plebeias", para contornar uma revolta dos populares que se retiraram de Roma contra os patrícios e se estabeleceram no monte Sacro, cercados de fosso e paliçada (JAEGER, 2002, p. 29-30; TITO LÍVIO, 1989, p. 149-150), motivo pelo qual talvez tenha sido feito cônsul em 503 B. C. (SMITH, 1952, p. 188). As expressividades retórica e literária do texto paulino recomendam sua reprodução:

Pois tal como o corpo é um e tem muitos membros, todos os membros do corpo, sendo muitos, são um corpo, assim como Cristo também [é]. E num espírito todos nós fomos batizados para [formarmos] um corpo, quer judeus, quer gregos; quer escravos, quer pessoas livre, e todos bebemos um espírito.

Pois o corpo não é um membro, mas muitos. Se o pé dissesse: "Porque não sou mão, não sou do corpo", não é da mesma forma do corpo? E se o ouvido dissesse: "Porque não sou olho, não sou do corpo", não é da mesma forma do corpo? Se todo o corpo [fosse] olho, onde [estaria] a audição? Se todo ele [fosse] audição, onde [estaria] o olfato?

Ora, Deus, dispôs os membros, cada um deles no corpo conforme Ele quis. Se tudo fosse um membro, onde [estaria] o corpo? Muitos membros [existem], porém [existe apenas] um corpo. Não pode o olho dizer à mão: "Não tenho necessidade de ti"; 
nem, por sua vez, a cabeça [pode dizer] aos pés: "Não tenho necessidade de vós". Mas quanto mais fracos parecem ser os membros do corpo, tanto mais são necessários, e aqueles que parecem ser os menos honrosos do corpo, a esses rodeamos de maior honra, e aqueles que são indecorosos, nós os tratamos com mais decoro; os nossos [membros] decorosos não têm necessidade [disso]. Mas Deus dispôs o corpo, tendo dado mais honra ao [membro] carente [de honra], para que não haja divisão no corpo, mas [para que] os membros se preocupem na mesma medida uns com os outros. E se um membro sofre, sofrem conjuntamente todos os membros; se um membro é honrado, todos os membros se regozijam. (1Coríntios 12,12-26).

Por outro lado, a demora da segunda vinda de Cristo (parusia) sedimentou um enrijecimento organizacional eclesiástico, fazendo com que ministérios permanentes se sobrepusessem aos carismas condicionados pelos casos. Quanto mais o tempo progredia, maiores eram as necessidades de se manterem os vínculos com a origem. Assim, o múnus eclesiástico se apresentou como garantia dessa vinculação com os primeiros tempos, na medida em que postou-se de modo subordinado a um esquema sucessório, legitimado por um forte arrazoamento teológico. A primeira carta de Clemente (depois santificado e considerado o terceiro bispo de Roma) aos coríntios, aproximadamente do ano 96, não deixa margem a dúvidas: Deus enviou Cristo que anunciou a Boa Nova aos apóstolos, que receberam incumbências e a pregaram, com o Espírito Santo, e instituíram seus primogênitos como bispos e diáconos confirmados, cujas funções já figuravam na escritura há séculos (1Clemente, 42, 1-5; LONGOBARDO, 2010, p. 203; STOCKMEIER; BAUER, 2013, p. 19-20).

Para além das funções diretivas, o epískopo único, também de forma paralela à figura do pater famílias, passa a exercer, crescentemente, uma jurisdição interna sobre os membros da sua família cristã. A fundamentação teológica da sucessão de Cristo pelos apóstolos e dos apóstolos pelos bispos legitimava o exercício dessa função de julgamento, uma vez que o próprio Jesus a teria conferido diretamente aos apóstolos: "quando o Filho da Humanidade se sentar no trono da sua glória, vós que me seguistes sentar-vos-ei em doze tronos a julgar as doze tribos de Israel" (Mateus, 19, 28). A fundamentação para o exercício da função jurisdicional interna também advinha da passagem paulina abaixo reproduzida - à qual serão acrescentados breves colchetes explicativos, ressalvada a nota do tradutor (NT) - , igualmente dirigida originariamente à comunidade de Corinto, mas que também tendeu a ser interpretada de modo universalizado:

Atreve-se um de vós, em litígio com outros, a ser julgado perante os injustos [os pagãos], e não os santos [os irmãos de fé]? Ou não sabeis que os santos julgarão o mundo? E, se é entre vós que o mundo é julgado, sois indignos de julgar questões menores [questões econômicas, por exemplo]? Não sabeis que julgaremos os 
anjos, quanto mas as pequenas coisas da vida? Quando, pois, tendes questões menores [negócios terrenos, na tradução de Almeida], por que escolheis como juízes os desprezados na congregação?

Digo [isso [NT]] para vossa vergonha. Não existe entre vós nenhum sábio, que conseguirá julgar no meio do seu irmão? Mas um irmão processa o seu irmão e isto diante dos não crentes? Para vós já é totalmente uma derrota que tenhais questões uns com os outros. Por que não preferis, antes, sofrer uma injustiça? Por que não preferis ser prejudicados? Mas, pelo contrário, sois vós que cometeis injustiças e causais prejuízos, e isso contra irmãos. (1Coríntios 6, 1-8)

A fundamentação divina do exercício da tarefa jurisdicional não era desconhecida pelo povo judeu (Deuteronômio 16, 18-22, e 17, 8-13). Paulo seguramente a tomou por base, bem como não tinha qualquer aversão absoluta às autoridades seculares: "Que toda a pessoa se submeta às autoridades superiores. Pois não existe autoridade a não ser sob [ordem de] Deus e as que existem foram estabelecidas por Deus" (Romanos 13, 1-2, mas significativo em todo o capitulo 13). A ideia subjacente à jurisdição interna era possivelmente constituída pelo propósito do aperfeiçoamento moral em Cristo das partes conflitantes, que deveriam manter ou implementar uma conduta irrepreensível, não merecedora de castigo ou correção (Romanos, 13, 3-5). Mas não só. Outro propósito, que foi incorporado pela progressão temporal e já se mostrava mais claro na literatura do século II, concernia ao temor de a causa do conflito ser motivo de escândalo entre os gentios, o que se deveria evitar para o bem da comunidade (BELDA INIESTA, 2015, p. 390-391) e convinha para o propósito dilatado de integração à sociedade romana.

\section{Conclusão}

Nascida nos limites de uma distante província romana, a nova religião cristã espraiou-se, com rapidez, pela ação de apóstolos e missionários anônimos junto às comunidades judaicas da palestina, aos judeus da diáspora e às comunidades gentílicas das principais cidades do império, com o apelo de uma mensagem de salvação indistinta para judeus e gentílicos, homens e mulheres, livres e escravos. Para a difusão da nova fé, os missionários valeram-se das infra-estruturas imperial e sinagogal, bem como do aproveitamento de muitas racionalidades, categorias de pensamento, conceitos, metáforas, conotações de sentido, formas e estilos literários gregos, língua em que a primeira literatura cristã é expressa e em que foi composto o Novo Testamento. A exclusividade das exigências rituais a um Deus único alijou os cristãos da participação da vida pública imperial, em que observado o culto ao imperador e às deidades tradicionais. Isso, aliado ao 
enfraquecimento dos laços sociais pretéritos, derivados do pertencimento a uma nova comunidade familiar doméstica solidária - praticante de ritos privados desconhecidos - , rendeu aos cristãos vasta desconfiança e antipatias públicas, que muitas vezes resultaram em denúncias anônimas e não anônimas às autoridades romanas, sem que isso tenha resultado em qualquer política imperial sistemática de extirpar a nova religião, mas que foram por si sós suficientes para introjetar nos primeiros cristãos sentimentos de receio, precariedade e perigo. A diversidade do cristianismo do primeiro século refletia-se na existência de várias congregações domésticas fracionadas, sem ortodoxia padronizada na fé, hierarquia eclesiástica ou instituições centralizadas. A circunstância de reunirem-se em casas particulares, no entanto, tornou necessário o relacionamento com o arraigado arranjo institucional da casa antiga, com o que múltiplas situações organizacionais se desembaraçavam com a mediação dos senhores das casas em que se reuniam as diversas comunidades. O modelo patriarcal da casa, por outro lado, também forneceu a base da futura forma organizacional que se consolidará na cristandade, conhecida como episcopado monárquico, com um único epíscopo ou bispo responsável pela unicidade doutrinal e pela ordem nas comunidades domésticas de uma mesma base territorial, havidas como sua morada. No início, os apóstolos eram os dotados da autoridade suprema na Igreja e as comunidades locais que tinham sido por eles fundadas gozavam de reputação supra-regional e legitimação dos estilos próprios de culto e condução da vida. Após as respectivas mortes, é que a questão da liderança e da autoridade se mostrava de maior complexidade. Os modelos de organização comunitária de tipo judaico e paulino foram os dominantes, mas se superpuseram em pouco tempo, com a condução das atividades diretivas a um colégio de presbíteros, num primeiro momento, seguido pela substituição do colégio por um só epískopo, que regerá de modo análogo à figura do pater famílias. A demora da segunda volta de Cristo determinou um enrijecimento das funções eclesiásticas. Esse fator, somado à tendência de interpretação universalizada da concepção paulina de unidade de todos os membros de Igreja em um só corpo em Cristo - a justificar um sentido de corresponsabilidade das diversas igrejas locais pelo destino de toda a cristandade - , legitimaram a construção da estruturação hierárquica rígida como modo de organização e de controle disciplinar interno na Igreja, analogamente ao modelamento jurídico-administrativo imperial, o que já se esboça em Clemente Romano e Inácio de Antióquia na viragem do primeiro para o segundo séculos. O epíscopo único, de modo paralelo ao pater famílias, também exercia funções jurisdicionais internas à 
comunidade, fundadas teologicamente no intuito de implementação moral em Cristo dos conflitantes e de evitar escândalo entre os gentios, o que conveniente para o propósito cristão de longo prazo de integração à sociedade romana.

\section{Fontes antigas}

BÍBLIA. Português. A Bíblia Sagrada. Tradução de João Ferreira de Almeida. 2. ed. Barueri: Sociedade Bíblica do Brasil, 2000.

BÍBLIA. Português. Novo Testamento: os quatro Evangelhos. Tradução do grego de Frederico Lourenço. São Paulo: Companhia das Letras, 2017. v. 1.

BÍBLIA. Português. Novo Testamento: Apóstolos, Epístolas, Apocalipse. Tradução do grego de Frederico Lourenço. São Paulo: Companhia das Letras, 2018. v. 2.

CASSIUS DIO. Roman History by Cassius Dio. Tradução de Earnest Cary. Harvard: Harvard University Press, 1924. Loeb Classical Library, v. 7. Disponível em: http://penelope.uchicago.edu/Thayer/E/Roman/Texts/Cassius_Dio/60*.html. Acesso em: 9 maio 2020.

CLEMENTE, Bispo de Roma (35-101 d.C). Primeira Epístola aos Coríntios. Apologistas Católicos. Webpage modificada em: 11 maio 2020. Disponível em: http://apologistascatolicos.com.br/obraspatristicas/index. php?af=ClementeRomanoCorinti os. Acesso em: 11 maio 2020.

DION CASSIUS. Histoire romaine de Dion Cassius. Traduite en français par E. Gros. Paris: Librairie de Firmin Didot Frère, 1866. t. 8, liv. 60. Disponível em: http://remacle.org/bloodwolf/historiens/Dion/livre60.htm. Acesso em: 9 maio 2020.

EUSÉBIO DE CESARÉIA. História eclesiástica. Tradução de Wolfgang Fischer. São Paulo: Fonte Editorial, 2019.

LACTANTIUS. Divine institutes. Tradução de Anthony Bowen and Peter Garnsey. Liverpool: Liverpool University Press, 2003.

PLÍNIO, CARTAS, LIVRO X. Tradução das epístolas trocadas entre Plínio, o Jovem, e Trajano. Tradução de Thiago David Stadler. Prometheus - Journal of Philosophy, v. 11, n. 28 esp, 2018. Disponível em: https://seer.ufs.br/index.php/prometeus/article/view/9281. Acesso em: 12 jun. 2020.

SUETÔNIO. Os doze césares. Tradução de João Gaspar Simões. Lisboa: Assírio \& Alvim, 2007.

TÁCITO. Annales. $2010 . \quad$ Disponível em: https://professoressaorru.files.wordpress.com/2010/02/tacito_annales.pdf. Acesso em: 9 maio 2020. 
TERTULIANO. Against Marcion. Book V. Tradução para o inglês de Peter Holmes. Buffalo, NY: Christian Literature Publishing Co., $1885 . \quad$ Disponível em: http://www.newadvent.org/fathers/03125.htm. Acesso em: 9 maio 2020.

TITO LÍVIO. História de Roma: ab urbe condita libri. Tradução de Paulo Matos Peixoto. São Paulo: Paumape, 1989. v. 1.

\section{Referências}

BAUMGARTNER, Mireille. A lgreja no Ocidente: das origens às reformas do século XVI. Lisboa: Edições 70, 2015.

BELDA INIESTA, Javier. El ministério judicial del obispo hasta el surgimento de la lex christiana (ss I-IV). Anuario de derecho canónico: revista de la Facultad de Derecho Canónico integrada en la UCV, n. 4, p. 387-401, abr. 2015. Disponível em: https://dialnet.unirioja.es/descarga/articulo/5030282.pdf. Acesso em: 12 jun. 2020.

BONI, Luis Alberto de. O estatuto jurídico das perseguições dos cristãos no império romano. TRANS/FORM/AÇÃO: Revista de Filosofia, v. 37 (esp.), p. 135-168, 2014. https://doi.org/10.1590/S0101-3173201400ne00009

BRANDÃO, Jacyntho Lins. Em nome da (in) diferença: o mito grego e os apologistas cristãos do segundo século. Campinas: Unicamp, 2014.

CANTOR, Norman F. Antiquity: from the birth of Sumerian civilization to the fall of the Roman Empire. New York: Harper Collins, 2014.

CITRONI, Mario et al. Literatura de Roma Antiga. Tradução de Margarida Miranda e Isaías Hipólito. Lisboa: Fundação Calouste Gulbenkian, 2006.

COLOGNESI, Luigi Capogrossi. Storia di Roma tra diritto e potere. Bologna: II Mulino, 2009.

CONSTANCIO, Francisco Solano. Novo diccionario critico e etymologico da língua portuguesa. Paris: Officina Typographica de Casimir, Angelo Francisco Carneiro Editor, 1836.

EBNER, Martin. A igreja na era pré-constantianiana: dos primordios até metade do século II. In: KAUFMANN, Thomas et al. (Org.). História ecumência da lgreja: dos primordios até a Idade Média. Tradução de Irineu J. Rabuske. São Paulo: Loyola: 2012. v. 1, p. 3-49.

FANTAPPIĖ, Carlo. Storia del diritto canonico e delle istituzioni della Chiesa. Bologna: ॥ Mulino, 2011.

GILSON, Etienne. A filosofia na Idade Média. Tradução de Eduardo Brandão. São Paulo: Martins Fontes, 2001.

GOULDER, Michael. As epístolas paulinas. In: ALTER, Robert; KERMODE, Frank (Org.). Guia literário da Bíblia. Tradução de Raul Filker. São Paulo: Unesp, 1997. p. 515-539. 
HARRIL, J. Albert. Saint Paul and the Christian communities of Nero's Rome. In: BARTSCH, Shadi; FREUDENBURG, Kirk; LITTLEWOOD, Cedric (Ed.). The Cambridge Companion to the Age of Nero. Cambridge (UK): Cambridge University Press, 2017. p. 276-289.

HOLMES, J. Derek; BICKERS, Bernard W. História da Igreja Católica. Tradução de Victor Silva. Lisboa: Edições 70, 2006.

JAEGER, Werner. Cristianismo primitivo e paideia grega. Tradução de Teresa Louro Pérez. Lisboa: Edições 70, 2002.

JOSSA, Giorgio. Dalle origini al concilio di Nicea. In: FILORAMO, Giovanni. Cristianenismo. Bari: Laterza, 2007. p. 3-53.

LE GLAY, Marcel et al. A history of Rome. Tradução de Antonia Nevill. 3. ed. Malden, MA: Blackwell, 2006.

LE ROUX, Patrick. Império romano. Tradução de William Lagos. Porto Alegre: L\&PM, 2009.

LONGOBARDO, Luigi. Os padres apostólicos. In: BERARDINO, Angelo di; FEDALTO, Giorgio; SIMONETTI, Manlio (Org.). Dicionário de literatura patrística. Tradução de José Joaquim Sobral. São Paulo: Ave Maria, 2010. p. 202-214.

MCKENZIE, Steven L. Como ler a bíblia: História, profecia ou literatura. Tradução de Andréa Mariz. São Paulo: Rosari, 2007.

MURPHY-O'CONNOR, Jerome. Jesus e Paulo: vidas paralelas. São Paulo: Paulinas, 2008.

PARENTI, Michael. O assassinato de Júlio César: uma história popular da Roma Antiga. Tradução de Berilo Vargas. Rio de Janeiro: Record, 2005.

PIERINI, Franco. Idade Antiga: curso de história da Igreja. Tradução de José Maria de Almeida. São Paulo: Paulus, 1998. v. 1.

POLLINI, John. Burning Rome, Burning Christians. In: BARTSCH, Shadi; FREUDENBURG, Kirk; LITTLEWOOD, Cedric (Ed.). The Cambridge Companion to the Age of Nero. Cambridge (UK): Cambridge University Press, 2017. p. 213-238.

ROBERTS, John (Ed.). The Oxford Dictionary of the Classical World. Oxford: Oxford University Press, 2005.

RUDEN, Sarah. Apóstolo Paulo. Tradução de Marcelo Musa Cavallari. São Paulo: Benvirá, 2013.

SIMONETTI, Manlio. Roma e papado. In: BERARDINO, Angelo di; FEDALTO, Giorgio; SIMONETTI, Manlio (Org.). Dicionário de literatura patrística. Tradução de José Joaquim Sobral. São Paulo: Ave Maria, 2010. p. 1441-1474.

SMITH, Sir William. Everyman's smaller classical dictionary. London: J. M. Dent \& Sons, 1952. 
Passagens: Revista Internacional de História Politica e Cultura Jurídica

Rio de Janeiro: vol. 13, ${ }^{0}$ 3, setembro-dezembro, 2021, p. 551-572.

STOCKMEIER, Peter; BAUER, Johannes B. Antiguidade. In: LENZENWEGER, Josef et al. (Ed.). História da Igreja Católica. Tradução de Fredericus Stein. 2. ed. São Paulo: Loyola, 2013. p. 7-114. 